From the IDepartment of Surgery, Division of General Surgery and the ${ }^{2}$ Center of Biomedical Research, University of Vienna, Austria, and ${ }^{3}$ Applied Immune Science, Santa Clara, California, USA

\title{
Gene Therapy in Surgery
}

\author{
Part Ill: Application to Septic Shock and to Organ Transplantation*) \\ M. A. Rogy ${ }^{1}$, Julie M. Baumhofer ${ }^{1}$, Britta Beinhauer ${ }^{1}$, H. Brandmeier ${ }^{1}$, P. Eisenburger ${ }^{1}$, U. M. Losert ${ }^{2}$, and Ramila Philip ${ }^{3}$
}

Key-words: Gene therapy-cancer - septic shock-organ transplantation.

Schlïsselwörter: Gentherapie - Karsinome -- septischer Schock Organtransplantation.

Summary: Background: With the increasing body of knowled ge in molecular biology, gene transfer respectively gene therapy becomes more and more a valid therapeutic option.

Methods: This is a critical review of gene therapy protocols for treatment of different types of cancer. Furthermore, the pathophysiological mechanism, therapeutically strategies as well as experimental approaches toward gene transfer in septic shock and organ transplantation are critically elucidated.

Results: Gene transfer as a therapeutic option was first successfully applied in children with severe combined immunodeficiency (SCID) in 1990. The majority of gene marking or gene therapy protocols approved for human clinical trials to date are related to the treatment of cancer. Besides viral vectors for brain tumors, non-viral vectors, liposomes particularly, with almost no side effects are increasingly used.

Conclusions: Different approaches of gene transfer in cancer patients are under investigation. Experimental data of septic shock treatment and rejection therapy of the allograft in organ recipients with gene transfer are encouraging for future applications in clinical trials.

(Acta Chir. Austriaca 1997;29:22-27)

\section{Gentherapeutische Strategien in der Chirurgie}

Anwendung bei septischem Schock und bei Organtransplantation

Zasammenfassung: Grundlagen: Die Fortschritte in der Molekularbiologie zusammen mit der Erforschung des „Humanen Genom"-Projektes lassen den Gentransfer bzw. die Gentherapie zunehmend als therapeutische Option bei verschiedensten Erkrankungen Eingang gewinnen.

Methodik: Die folgende Arbeit stellt einen kritischen Überblick über die klinischen Protokolle der Gentherapiestudien bei Karzinomen dar. Weîers werden der pathophysiologische Mechanismus, die verschiedenen Therapieansätze sowie der erfolgreiche, experimentelle Gentransfer im septischen Schock wie auch bei der Organabstoßung nach Transplantation dargestellt.

Ergebnisse: Der erste erolgreiche Gentransfer wurde bereits 1990 bei Kindern mit ., schwerem kombinierten Immundefekt" (SCID) durchgeführt. Die meisten Gentransferprotokolle behandeln verschiedene Karzinome. Neben viralen Vektoren, die sich besonders gut für nichtproliferierende Gewebe, z. B. zentrales Nervensystem, eignen, werden zunehmend nichtvirale Vektoren, insbesondere Liposomen verwendet.

*) Part I: Methods for Gene Transfer - Application to Cancer was published in Acta Chir Austriaca 1996;28:358-361.

Cortesponding address: M. A. Rogy, M.D., Division of General Surgery, Department of Surgery, University of Vienna, Währinger Gürtel 18-20, A-1090 Vienna.
Schlußfolgerungen: Neben der bereits erfolgreichen Anwendung des Gentransfers bei der Behandlung verschiedener Malignome, lassen experimentelle Daten auch einen erfolgreichen Einsatz des Gentransfers beim septischen Schock und bei der Abstoßungstherapie nach Organtransplantation erwarten.

\section{Background}

The reported mortality to septic shock varies between 25 and $50 \%$. Although controversy exists over the frequency and morbidity associated with sepsis and septic shock, there is agreement that the incidence of septic shock is increasing and mortality rates are remaining relatively constant despite marked improvements in anti microbial therapies and pulmonary and cardiovascular support. Even with constant improvements in supportive care, increases in immunocompromized diseases like AIDS, as well as the aging of the population, have resulted in an increased preposition to sepsis and septic shock.

In 1986/87, Beutler, Tracey, Cerami and Lowry demonstrated that overproduction of the proinflammatory cytokine, TNF- $\alpha$. was antecedent to shock and death (36-39). Initial studies demonstrated that the panoply of host responses seen in lethal endotoxemia or gram negative bacteremia could be reproduced in healthy animals simply by administering recombinant TNF- $\alpha$. In subsequent studies in mice and Papio (baboon), the authors demonstrated that an exaggerated endogenous TNF- $\alpha$ response inhibitable with polyclonal and monoclonal antibodies, contributed to the mortality associated with endotoxemia and gram negative bacteremia (40). Since 1987 when the studies were first reported there have been at least 15 studies confirming the central role that TNF- $\alpha$ plays in acute gram negative bacteremia and endotoxemia (for review see Bone [41]) (42).

Similarly, in 1988. Waage et al. (43) and Schreiber et al. (44) each reported that TNF- $\alpha$ toxicity could be potentiated by co-administration of either IL-1 or lipopolysaccharide. As early as 1989, Fong et al. (45) reported that blocking an endogenous TNF- $\alpha$ response in gram negative septic shock with monoclonal antibodies led to an attenuated IL- 1 and IL-6 response. Ohlsen et al. (46) and subsequently Dinarello et al. (47), Norton et al. (48) and Fisher et al. (49) reported that blocking an endogenous IL-1 response with JL-1 receptor antagonist (IL-l ra) also improved survival and reduced tissue damage associated with lethal gram negative bacteremia.

Since then a considerable body of knowledge has developed to explain the mechanism and pathways by which the pronflammatory cytokines initiate and propagate shock, tissue damage and the sepsis syndrome (50). Investigators have implicated additional pro-inflammatory cytokines in the pathogenesis of overwhelming gram negative infections or endotoxemia, including interferon- $\gamma$, IL-6, LiF/Factor D and IL-12 (51, 52. 53). Although the role that each of these specific cytokines play in the pathogenesis of septic shock is still being resolved, there is general agreement that endogenous production of TNF- $\alpha$ and IL- 1 are central to initiating and sustaining the proinflammatory cytokine cascade. These 2 mediators in particular TNF- $\alpha$ appear very early in the inflammatory response, and their synthesis and release begins within minutes of macrophage activation $(50,54)$. The early re- 
lease of TNF- $\alpha$ initiates a subsequent cascade of other cytokines and mediators. When TNF- $\alpha$ or IL- 1 are inhibited with either antibodies or receptor antagonists, the major components of the inflammatory response are suppressed $(39,55)$.

It is now generally accepted that the catastrophic host responses to overwhelming bacterial infections represent an aberrant relationship between proinflammatory cytokines, TNF- $\alpha$ and IL-1, and their naturally occurring inhibitors (56). In lethal bacteremia and endotoxemia the concentrations of TNF- $\alpha$ and IL-1 $\beta$ in the plasma are far greater than can be neutralized by the corresponding levels of shed TNF receptors (TNFR p55 \& p75) or IL-1 Ira. Similarly, in ongoing inflammatory processes, such as those which occur in hospitalized patients with systemic inflammatory response syndrome (SIRS) or sepsis syndrome, the mechanisms which ultimately down-regulate proinflammatory cytokine release are ineffective. This is due in part to the continued external stimuli which ongoing infectious or inflammatory processes invoke. In such cases repeated or persistent proinflammatory cytokine synthesis (TNF- $\alpha$, IL-1) contributes to the hemodynamic instability, coagulopathy, and multiorgan dysfunction that occurs. In both septic shock and SIRS, the beneficial aspects of proinflammatory cytokine production (including stimulation of nonspecific host immunity, increased antigen specific T-cell proliferation, macrophage and $\mathrm{NK}$-cell bactericidal capacity) are offset by the adverse consequences of continued exposure to elevated TNF- $\alpha$ and IL-1 concentrations.

\section{Clinical trials}

Successful anticytokine approaches to the treatment of septic shock or sepsis syndrome associated with bacteremia or endotoxemia have been directed at either suppressing the proinflammatory cytokine (TNF- $\alpha$ or IL-1) response, such as with IL-10 or TGF- $\beta$, or blocking TNF- $\alpha$ and IL- 1 activity with antibodies or by increasing pharmacologically the levels of cytokine inhibitors with recombinant IL-1ra and soluble TNF receptors. The preclinical rodent and subsequent primate studies which demonstrated efficacy with either antibodies (anti-TNF- $\alpha$ mAb) or cytokine inhibitors (IL-1 ra or soluble TNF receptors TNFR) in lethal endotoxemia and gram negative bacteremia prompted the initiation of clinical trials in patients with sepsis syndrome and shock. At the present time, there have been at least 6 clinical trials initiated with either anti-IL-1 or anti-TNF- $\alpha$ therapies. Reports of preliminary results have suggested a variable clinical response $(57,58)$. The initial promising Phase II report of improved outcome in patients with sepsis syndrome treated with IL-1ra could only be confirmed in the Phase III trials with a subgroup of critically ill patients with predicted mortalities of greater than $24 \%$ by APACHE III scores (59). In fact, clinical trials with IL-1 ra have been discontinued, and IL-1 ra is no longer under clinical investigation. Beneficial results from the anti TNF- $\alpha$ monoclonal antibody studies have also been conditional. For example, Fisher reported an improvement in outcome only in those patient with detectable plasma TNF- $\alpha(58)$.

In light of the observation that these clinical studies can only confirm the utility of anticytokine therapies for the treatment of shock and sepsis syndrome in very selected patient populations, interest has focused primarily on identifying prospectively patient that may benefit from such therapies. In fact, retrospective analysis of Phase II and II cinical trials with TN-a antibodies and IL-1 inhibitors revealed that only some patients subpopulations benefited from anticytokine therapies, whereas there was a trend towards increased mortality in other patient populations $(57,58,59)$. In particular, anti $\mathbb{L}-1$ and anti TNF- $\alpha$ therapies appeared to be most helpful in patients who had organ failure or were already in shock, whereas they were least beneficial (and potentially hazardous) in patients at risk of developing septic shock, but not as critically ill.

The inability of these several clinical trials to unequivocally demonstrate efficacy of this novel approach does not indicate a failure of the underlying concept, but rather a failure in its implementation. Such results are not surprising given the fact that cy- tokines have both concurrent beneficial and pathologic roles. In fact, Echtenachter demonstrated that blocking an endogenous TNF- $\alpha$ response made a non lethal peritonitis model lethal (60). Similarly, van der Meer and Czyprinski demonstrated that administration of IL-1 improved outcome to a variety of gram negative bacterial infections and blocking an endogenous IL-1 response inhibited antimicrobial processes $(61-64)$. Such results suggest that an endogenous proinflammatory cytokine response can have beneficial responses, and efforts to block an endogenous TNF- $\alpha$ or IL-1 response may have untoward negative effects.

We believe that identifying the optimal patient population who can benefit from such therapies will only partially address the problems associated with the current approaches for delivering anticytokine therapies. A major difficulty with the current strategy of infusing systemically either inhibitors of IL-1 (IL-l ra) or TNF- $\alpha$ (monoclonal antibodies or soluble receptors), or infusing antiinflammatory mediators (such as glucocorticoids, IL-4, TGF$\beta, I L-10$ or IL-13) is that systemic administration is an imprecise means of directing an anticytokine therapy to individual body compartments where exaggerated production is occurring. Similarly, because such therapies are inherently aimed at blocking cytokines primarily in the vasculature, but also in all organs of the body, they can be potentially hazardous to some patient populations where an organ specific cytokine production may have beneficial antimicrobial functions.

Systemic administration of cytokine inhibitors may in fact be an inappropriate means to block the paracrine actions of a cytokine. Only recently has a greater appreciation for the paracrine nature of TNF- $\alpha$ and IL- 1 been recognized. Both IL- 1 and TNF$\alpha$ are known to exist in cell associated forms and retain some biologic activity $(65,66)$. Ginsberg et al. (67) reported in mice suffering adeno-virus induced hemorrhagic pneumonia local, but not systemic, production of TNF- $\alpha$ and IL-1. TNF- $\alpha$ and IL-1 levels in the lung were often in excess of $10 \mathrm{ng} / \mathrm{ml}$ whereas plasma concentrations were less than $50 \mathrm{pg} / \mathrm{ml}$ and could not be detected by either immuno- or bioassays. Similarly, in rats expiring from a thermal injury and Pseudomonas infection, local but not systemic TNF- $\alpha$ production was reported $(68,69)$. Ulich has reported lung TNF- $\alpha$ levels exceeding $10 \mathrm{ng} / \mathrm{ml}$ in mice following intratracheal instillation of LPS, whereas levels in the plasma were less than $100 \mathrm{pg} / \mathrm{ml}$ (70). Similar findings have been seen with patients with ARDS $(71,72)$. In such patients, TNF- $\alpha$ was recovered from the lungs of patients with ARDS at levels as high as $15 \mathrm{ng} / \mathrm{ml}$, whereas concentrations in the plasma were only $100 \mathrm{pg} / \mathrm{ml}$. Thus, systemic administration of cytokine inhibitors must be given at levels sufficient to block the elevated concentrations in the tissues and not in the plasma compartment. This is exceedingly problematic since anti TNF- $\alpha$ monoclonal antibodies, soluble receptor fusion proteins and even IL- 1 ra are primarily sequestered in the plasma compartment $(49,56,73)$.

Systemic administration of cytokine inhibitors is also problematic since the natural antagonists or inhibitors of TNF- $\alpha$ and IL-1 often have short biological half-lives, ranging from minutes to hours. For example, Fisher et al. reported that in the septic primate, IL-1 ra has a biological half-life (beta phase) of approximately $21 \mathrm{~min}(49)$. To sustain therapeutic plasma concentrations of 10 to $15 \mathrm{mg} / \mathrm{ml}$, IL- 1 ra and soluble TNF receptors have to be given at concentrations of 1.5 to $2 \mathrm{mg} / \mathrm{kg}$ body weight/h or approximately $2.5 \mathrm{~g} / \mathrm{d}$ for as long as the patient is septic. Such an approach may not be cost-effective. To some extent, these problems have been obviated by the use of antibodies or TNF receptors that are joined to the FC and hinge region of human IgG. This "Chimeric fusion" proteins have a biological half life between 20 to 60 h $(57,73)$.

Finally, exaggerated proinflammatory cytokine production may contribute to the pathology in one body compartment, while simultaneously, production in another compartment may actually have beneficial effects. There has been little examination into the differential organ response to a variety of lethal and non lethal infections or inflammation. The implications of these findings are considerable. Systemic administration of cytokine inhibitors at 
levels sufficient to exit the plasma pool in quantities sufficient to neutralize exaggerated TNF- $\alpha$ production in one tissue compartment may also block the presumably beneficial aspects of cytokine production in other tissue compartments. This latter point may explain some of the experimental observations where TNF$\alpha$ inhibition is associated with adverse outcome.

In 1986, Beutler and Cerami characterized TNF- $\alpha$ 's actions as being 2 sides of the same coin (74). Even at that time it was understood that the biological actions of proinflammatory cytokines were in general beneficial to the host. Since then, considerable experimental data has arisen to suggest that an endogenous TNF$\alpha$ or IL- 1 response is critical to a normal non-specific host response that serves to reduce the amount of tissue damage and the likelihood of a secondary bacterial infection. It has been well recognized that endogenous TNF- $\alpha$ and IL- 1 production contributes to the antimicrobial responses against several intracellular pathogens, such as listeria and pneumocystis (75). An endogenous TNF- $\alpha$ and IL-1 response, particularly in the liver and spleen, are essential to the anti-listerial response. In addition, there is also increasing appreciation for a beneficial role for TNF and IL-1 in the host response to gram negative bacterial infections (76). For example. Echtenachter et al. reported that passively immunizing mice against TNF- $\alpha$ converted an otherwise non lethal peritonitis (cecal ligation and puncture) into a uniformly lethal one (60). Similarly, Dinarello reported that some IL-1 production was critical in newborn rodents (76). He demonstrated that exaggerated IL-1 production could be lethal as an inade quate IL-1 production in a murine model of gram negative infection. The findings confirm that some IL-1 production is essential for eliciting an antimicrobial response, but either too much or too little is disadvantageous.

For the reasons described above, we propose that gene transfer of antiinflammatory cytokines or cytokine inhibitors represents a more efficient means to block proinflammatory cytokine action in tissue compartments than does the systemic administration of these same agents.

Use of gene transfer to deliver anticytokine therapies directly to organs and tissues

We propose to employ gene transfer as a novel drug delivery system to transiently mitigate the inflammatory response in individual tissues and organs. We believe that coupling gene transfer technologies with surgical intervention and manipulation ultimately offers a unique means to modify the post-surgical and inflammatory response, by either down-regulating inflammatory processes in tissues where exaggerated production occurs, or in cases where up regulating the inflammatory response may stimulate antimicrobial processes. Based on this proposal, gene transfer technologies would be an integral component of the surgeon's armamentarium, aimed at modulating wound healing, tissue regeneration and decreasing inflammatory cell-mediated injury.

The specific goals of gene therapy for sepsis and acute inflammation therefore differ in some important regards from efforts to correct germline disorders. Whereas the treatment of such germline disorders as ADA deficiency-induced SCID or cystic fibrosis seeks a stable integration of the foreign gene into the target tissue genome $(77,78,79)$, the goal of gene transfer in sepsis or acute intammation is a transient, non-stable transformation that resuls in maximal gene expression lasting days and at most weeks. in the case of down regulating an inflammatory response, stable integration of the gene for a antiinflammatory cytokine or cytokine inhibitor with a viral promoter-enhancer into the target cell genome could have adverse long lasting effects. including immune suppression and oncogenesis. Such stable transfections are therefore not desirable. In addition to non-stable transfection, gene therapy approaches in sepsis are aimed at targeting several cell populations simultaneously in a single organ or tissue, such as pulmonary macrophages, or epithelial and endothelial cells in the lung. Under ideal conditions, the target cell population in sepsis is one in which excessive production of the proinflammatory cy-
Table 3. Survival and peak TNF concentrations in LPS-D-GalN mice pretreated with liposomes containing $p C M V / p 55$ or $p c D-S R-a / / L-10$ (80).

\begin{tabular}{|c|c|c|c|}
\hline Experiment number & pCMV/p55 & PCD-SR-a/hIL-10 & Controls \\
\hline & survived/total & survived/total & survived/total \\
\hline 1 & 4 of 6 & 6 of 6 & 1 of 6 \\
\hline 2 & 3 of 6 & 4 of 6 & 0 of 6 \\
\hline 3 & 3 of 6 & 6 of 6 & 1 of 6 \\
\hline Totals & 10 of $18^{*}$ & 16 of $18 *$ & 2 of 18 \\
\hline TNF pg/ml & $2080 \pm 810$ & $190 \pm 60 * *$ & $2690 \pm 660$ \\
\hline
\end{tabular}

$* p<0.01$ vs. control by Fisher's exact test: ${ }^{*: 15} p<0.05$ vs. control by ANOVA and Newman-Keuls multiple range test

tokines IL-1 and TNF- $\alpha$ occurs, although it is recognized that current strategies are likely not to be that precise.

Our own experimental results underscore several advantages for the use of gene transfer as a treatment option for septic shock or other acute inflammatory episodes (80). In these studies, human gene transfer was used to deliver to organs of the reticuloendothelial system antagonists that either inhibit TNF- $\alpha$ synthesis or block its interaction with cellular receptors. Mice were treated intraperitoneally with cationic liposomes containing $200 \mu \mathrm{g}$ of either a pCMV (cytomegalovirus)/p55 expression plasmid that contains the extracellular domain and transmembran region of the human p55 TNF receptor, or a pcD-SR-a /hIL-10 expression plasmid containing the DNA for human IL-10. $48 \mathrm{~h}$ later, mice were challenged with lipopolysaccharide (LPS) and D-galactoseamine. Pretreatment of mice with p55 or IL-10 cDNA-liposome complexes improved survival $(\mathrm{p}<0.01)$ to LPS-D-galactosamine (Table 3 ). In additional studies, intratracheal LPS challenge reduced pulmonary TNF- $\alpha$ levels by $62 \%$ and decreased neutrophil infiltration in the lung by $55 \%$ as measured by myeloperoxidase activity (both $\mathrm{p}<0.05$ )

\section{Application of gene therapy to organ transplantation}

In 1945 Sir Peter Medawar, the English immunologist, appreciated that rejection in organ transplantation was an immune reaction - following recognition by the immune system that a graft is "foreign" and must be destroyed. If rejection was an immune event, what could be more logical than to try to protect grafts by altering the immune system? At the beginning of kidney transplantation total body $\mathrm{X}$-ray of a kidney recipient was performed in order to weakening the immune system (81). With the development of new "antilymphocytic agents" the results in organ transplantation including kidney, liver, heart, lung and pancreas were improving successfully (82-85). However, toxic side effects due to "systemic" immuno-suppression are still a valid concern in the post operative management in these patients.

Therefore, the concept of local immuno-suppression by organ targeted therapies is also of most interest in organ transplantation. Gene transfer to organ transplantation offers the potential for modulation of immunity directly within an allograft without systemic side effects. Qin et al. $(86,87)$ demonstrated already in a series of experiments that gene transfer for heart transplantation can induce transient expression of a immunologically relevant cytokine (TGF-B1) within allografts that impede immune activation while avoidng the systemic toxicivy of conventional immuno-suppression. With their murine experiments $Q i n$ et al. demonstrated firstly that syngeneic grafts injected with pRSV $\beta$-gal displayed $\beta$-gal activity between 9 and 14 days after transplantation. These experiments demonstrate that purified, naked plasmid DNA can transfer into and express exogenous nucleic acids in cardiac isografts. Next, it is demonstrated that transfer and expression of an immuno-suppressive cytokine (TGF- $\beta 1$ ) prolongs graft survival to $26.3 \pm 2.5$ days $(\mathrm{p}<0.02)$.

The encouraging findings in these experiments is the fact that recipients of transfected allografts showed no apparent toxic effects and no mortality associated with the plasmid transfer. The issue of whether simple injection of recombinant, purified TGF- 
$\beta 1$ protein also could prolong allograft survival also was addressed. Injection of excess amount of rTGF- $\beta$ I into the allograft at the time of grafting showed no effect on allograft survival. This suggests that gene transfer results in extended temporal expression of the gene product and provides for prolonged immunosuppressive effects within the graft.

The authors also investigated a possible toxicity of the gene product, since TGF- $\beta 1$ has been demonstrated to be associated with exuberant fibrosis in a variety of systems. Thus, expression of TGF- $\beta 1$ may also cause toxicity. However, histology could not confirm any fibrosis, inflammation, or other evidence of graft destruction. The authors conclusion include that transient expression of TGF- $\beta 1$ may be advantageous for allografting. Such expression at the time of initial grafting could provide the appropriate signals to negatively regulate the initiation of an immune response, which could prevent or delay graft rejection. With IL10 , another immuno-suppressive cytokine, the authors already demonstrated a more prolonged allograft survival. To achieve further immuno-suppression or induce tolerance, it will be necessary to enhance gene transfection efficiency and transgene expression.

Another conceptionally promising perspective is to irreversibly induce alloantigen-specific $T$ cell non-responsiveness (i.e., T cell anergy). The receptor ligand pairs CD28-B7 (expressed on T cells and Antigen Presenting Cells [APC], respectively) are essential for the initiation and amplification of T cell-dependent immune responses. Importantly, antigen recognition by $T$ cells in the absence of $\mathrm{CD} 28$ co-stimulation leads to the induction of antigen-specific anergy in many systems. Nevertheless, newer data suggest that the elicitation of allospecific $T$ cell responses in vivo not only depend on B7-CD28 interactions but concommittantly require interaction of CD40 and CD40 ligand on $A P C$ and $T$ cells, respectively. In fact, fascinating experiments by Larsen et al. (88) demonstrate that the simultaneous but not independent blockade of the CD28/B7 and CD40/CD40 ligand pathways effectively aborts clonal $\mathrm{T}$ cell expansion in vitro and in vivo, promotes longterm survival of allogeneic skin grafts, and inhibits the development of chronic vascular rejection of primarily vascularized cardiac allografts. It remains to be evaluated whether gene transfer, e.g., of IL-10, which reportedly inhibits the upregulation of B7 expression in vitro (89), can be used to inactivate the $\mathrm{CD} 28 / \mathrm{B} 7$ and $\mathrm{CD} 40 / \mathrm{CD} 40$ co-stimulatory pathways in vivo.

\section{Conclusions}

The successful application of gene therapy will continue to require the efforts of investigators in basic science, since basic science issues (e.g. transfection efficacy) underlie many of the problems that need to be overcome in order for gene therapy to succeed. In some countries gene therapy is already discussed to become a subspeciality in medicine with physicians in this field performing gene therapy like us performing surgery. Although the medical potential of gene therapy is bright, the possibility for misuse of genetic engineering technology looms large, so society must ensure that gene therapy is used only for the treatment of disease. With both sides of this possibility in mind, somatic gene therapy will become a new and exciting therapeutic option for heritable and acquired disease.

\section{Adrinowledgmonts}

We thank Dr. Lyle L. Moldawer, Professor of Surgery, University of Florida in Gainesville, for his encouragement and strong support for the development of gene transfer strategies for therapy of septic shock. This work was supported in part by the "Erwin Schrödinger Stiftung" of the "Fonds zur Förderung der wissenschaftlichen Forschung" (FWF) Austria.

\section{References}

(1) Blaese RM. Culver KW, Anderson WF: The ADA human gene therapy clinical protocol. Hum Gene Ther 1990;1:331-36?

(2) Ascadi G, Dickson G, Love DR, et al: Human dystophin expression in mdx mice after intramuscular injection of DNA constructs. Nature 1991;352:815-818.

(3) Zhu N. Liggitt D, Debs R: Systemic gene expression after intravenous DNA delivery into adult mice. Science 1993;261:209-211.
(4) Felgner PL, Gadek TR, Holm M, et al: Lipofection: a highly efficient, lipid mediated DNA transfection procedure. Proc Natl Acad Sci 1987:84:7413-7417 (5) Philip R. Liggiu D. Philip M, Dazin B. Debs R: In vivo gene delivery. Efficien transfection of T lymphocytes in adult mice. J Biol Chem 1993;268:16087-16090. (6) Wu GY, Wu CH: Receptor mediated in vitro gene transformation by a soluble DNA carrier system. J Biol Chem 1987;262:4429-4432.

(7) Wollf JA, Malone RW, Williams P, Chong W, Ascardi G, Jani A, Felgner P: Direct gene transfer into mouse muscle in vivo. Science 1990;247:1465-1468.

(8) Dranoff G, Jaffee E. Lazenby A, Golumbeck B, et al: Vaccination with irradiated tumor cells engineered to secrete murine granulocytemacrophage colony-stimulating factor stimulates potent, specific, and long lasting anti-tumor activity. Proc Natl Acad Sci USA 1993:90:3539-3543.

(9) Brenner MK, Furman WL, Santana VM, Bowman L, Meyer W: Phase I study of cytokine gene modified autologous neuroblastoma cells for treatment of relapsed/refractory neuroblastoma. Hum Gene Ther 1992;3:665-676.

(10) Culver KW, Ram Z. Walbridge S, et al: In vivo gene transfer with retroviral producer celis for treatment of experimental brain tumors. Science 1992:256:1550-1552.

(11) Gänsbacher B. Motzer R, Houghton A. Bander N: A pilot study of immunization with interleukin-2 secreting allogeneic HLA-A2 matched renal cell carcinoma cells in patients with advanced renal cell carcinoma. Hum Gene Ther 1992;3:691-703. (12) Golumbek PT, Lazenby AJ, Levitsky HI, et al: Treatment of established renal cell cancer by tumor cells engineered to secrete interlcukin-4. Science 1991;254:713-716. (13) Kay MA. Li O. Liu TJ, et al: Hepatic gene therapy: Persistent expression of human o.1-antitrypsin in mice after direct gene delivery in vivo. Hum Gene Ther 1992;3:641-647.

(14) Yang NS, Burkholder J, Roberts B, Martinelli B. Mc Cabe D: In vivo and in vitro gene transfer to mammalian cells by particle bombardment. Proc Natl Acad Scl USA 1990;87:9568-957?

(15) Blaese RM: Development of gene therapy for immunodeficiency: Adenosine deaminase deficiency. Pediatr Res 1993:33 (Suppi): S49-S55.

(16) Blaese RM. Culver KW, Anderson WF, et al: Treatment of severe combined immunodeficiency disease (SCID) due to adenosine deaminase deficiency with CD34+ selected autologous peripheral blood cells transduced with a human AD. gene. Hum Gene Ther 1993;4:521-527.

(17) Hsueh JL, Oiu X. Zhou J, et al: Clinical protocol of human gene transfer for hemophilia B. Hum Gene Ther 1992;3:543-552.

(18) Beutler E: Gaucher disease;New molecular approaches to diagnoseis and treatment. Science 1992;256:794-799.

(19) Harrison GS, Long CJ. Curiel TJ, Maxwell F, Maxwell IF: Inhibition of human immunodeficiency virus-1 production resulting from transduction with a retrovirus containing an HIV-regulated diphteria toxin A chain gene. Hum Gene Ther 1992:3: $461-469$

(20) Crystal RG: Gene therapy strategies for pulmonary disease. Am J Med 1992:92:44S-52S

(21) Dickson G. Love DR. Davies KE, Wells KE. Piper TA. Walsh FS: Humin dystrophin gene transfer: production and expression of a functional recombinant DNA-based gene. Hum Genet 1991;88:53-58.

(22) Jones SN, Grompe M, Munir M, Veres MI, Craigen G. Caskey CT: Ectopic correction of omithine transcarbamylase deficiency insparse mice. $\mathrm{J}$ Biol Chem 1990:265:14681-14690.

(23) Shen L, Chen CW, Miller MD, et al: Recombinant virus vaccineinduced SIV-specific CDB+ cytotoxic T lymphocytes. Science 1991:252:140-143.

(24) Rosenberg SA. Aerbersold P. Cornetta K. et al: Gene transfer into humans Immunotherapy of patients with advanced melanoma, using tumor infiltrating lymphocytes modified by retroviral gene transduction. N Engl J Med 1990:323:570-578. (25) Rosenberg SA, Kasid A. Anderson WF, et al: TNF/TIL human gene therapy clinical protocol. Hum Gene Ther 1990;1:443-462

(26) Van Zee KJ. Stackpole SA. Montegut WJ, Rogy MA, et al: A human tumor necrosis factor (TNF) $\alpha$ mutant that binds exclusively to the p55 TNF receptor produces toxicity in the baboon. J Exp Med 1994;179:1 I 85-1191.

(27) Rosenberg SA. Anderson WF. Blaese RM, et al: Immunization of cancer patients using autologous cancer cells modified by insertion of the gene fo interleukin-2. Hum Gene Ther 1992:3:75-90.

(28) Osanto S, Brouwenstyn N, Vaessen N, Figdor CG. Melief CJM. Schrier PI: Immunization with interleukin-2 transfected melanoma cells: A phase I-Il study in patients with metastatic melanoma. Hum Gene Ther 1993:4:323-330.

patients with metastatic melanoma. Fim Gene Ther $1993: 4: 323-330$. HLA-A2 matched allogeneic melanoma cells that secrete interleukin-2 in patients with metastatic melanoma. Hum Gene Ther 1992:3:677-690.

(30) Nabel GJ, Chang A, Nabel EG, Plautz G: Immunotherapy of malignancy by in vivo gene transfer into tumors. Hum Gene Ther 1992;3:399-10.

(3I) Townsend SE, Alkison JP: Tumor rejection after direct costimulation of CDB+T cells by B7-transfected melanoma cells. Science 1993;259:368-370.

(32) Moolten FL. Wells JVI: Curability of tumors bearing herpes thymidine kinase genes transferred by retroviral vectors. I Nat Cancer Inst 1990:82:297-300.

(33) Mullen CA: Metabolic suicide genes in gene therapy. Pharmacol Ther (33) Mullen CA

1994:63:199-207. oligonucleotides. Anticancer Drug Design 1991:6:569-584

(35) Jacoby RF, Marshall Dj, Kailas S. Schlack S. Harms B. Lore R: Genetio instability associated with adenoma to carcinoma progression in hereditary non-polyposis colon cancer (HNPCC). Gastroenterol 1995;109:73-82.

(36) Tracey $\mathrm{KJ}$, Wei $\mathrm{H}$ Manome KR. Fong $Y$ Hesse D, et al Cachectin/tumor necrosis factor induces cachexia, anemiz, and inflammation. $J$ Exp Yed necrosis factor ind
$1988: 167: 1211-1227$

(37) Tracey KJ. Lowry SF, Fahey TJ, Albert JD, Fong Y, Hesse D. et al: Cachectin/tumor necrosis factor induces lethal shock and stress hormone responses in the dog. Surg Gynecol Obstet 1987:164:415-422.

(38) Beutler B, Krochin N, Milsark IW, Luedke C. Cerami A: Control of cachectin (tumor necrosis factor) synthesis: mechanisms of endotoxin resistance. Science 1986:232:977-980.

(39) Cerami A: Tumor necrosis factor as a mediator of shock, cachexia and inflam(39) Cerami A: Tumor necrosis factor
mation. Blood Purif 1993:11:108-117

(40) Tracey KJ. Fong Y. Hesse DG, Manogue KR, Lee AT, Kuo GC, Lowry SF, Cerami A: Anti-cachectin/TNF monoclonal antibodies prevent septic shock during lethal bacteraemia. Nature 1987:330:662-664 
(41) Bone RC: Monoclonal antibodies to tumor necrosis factor in sepsis: help or harm? Crit Care Med 1993:21:311-312

(42) Rogy MA, Moldawer LL, Oldenburg HSA, Thompson WA, et al: Antiendotoxin therapy in primate bacteremia with HA-1 A and BPI. Annais Surg 1994;220:77-85.

(43) Waage A. Espevik T: Interleukin I potentiates the lethal effect of tumor necrosis factor alpha/cachectin in mice. J Exp Med 1988:167:1987-1992.

(44) Rothstein JL, Schreiber H: Synergy between tumor necrosis factor and bacterial products causes hemorrhagic necrosis and lethal shock in normal mice. Proc Natl Acad Sci USA 1988;85:607-611.

(45) Fong Y, Tracey KJ, Moldawer LL, Hesse DG, Manogue KB, Kenney JS, et al: Antibodies to cachectin/tumor necrosis factor reduce interleukin 1 beta and interleukin 6 appearance during lethal bacteremia. J Exp Med 1989;170:1627-1633.

(46) Ohlsson K, Bjork P. Bergenfeldt M. Hageman R, Thompson RC: Interleukin-1 receptor antagonist reduces mortality from endotoxin shock. Nature 1990;348:550-552. (47) Wakabayashi G, Gelfand JA, Burke JF, Thompson RC, Dinarello CA: A specific receptor antagonist for interleukin 1 prevents Escherichia coli-induced shock in rabbits. FASEB J 1991;5:338-343.

(48) Alexander HR, Doherty GM, Venzon DJ, Merino MJ, Fraker DL, Norton JA: Recombinant interleukin-I receptor antagonist (IL-Ira): effective therapy against gram-negative sepsis in rats. Surgery 1992;112:188-193.

(49) Fischer E, Marano MA, Van Zee KJ, Rock CS, Hawes AS, Thompson WA, et al: Interleukin-1 receptor blockade improves survival and hemodynamic pertormance in Escherichia coli septic shock, but fails to alter host responses to sublethal endotoxemia. J Clin Invest 1992;89:1551-1557.

(50) Rogy MA, Oldenburg HSA, Coyle S, Trousdale R, Moldawer LL, Lowry SF: Correlation between APACHE III and immunological parameters in critically ill septic patients. Br J Surg (in press).

(51) Alexander HR, Doherty GM, Venzon DJ, Merino MJ, Fraker DL, Norton JA: Recombinant interleukin-1 receptor antagonist (IL-1 ra): effective therapy against gram-negative sepsis in rats. Surgery 1992;1 12:188-193.

(52) Block MI, Berg M, McNamara MJ, Norton JA, Fraker DL, Alexander HR: Passive immunization of mice against $D$ factor blocks lethality and cytokine release during endotoxemia. J Exp Med 1993; 178:1085-1090.

(53) Beutler BA, Milsark IW, Cerami A: Cachectin/tumor necrosis factor: production, distribution, and metabolic fate in vivo. J Immunol 1985;135:3972-3977.

(54) Granowitz EV, Vannier E, Poutsiaka DD, Dinarello CA: Effect of interleukin-1 (IL-1) blockade on cytokine synthesis: II. IL-1 receptor antagonist inhibits lipopolysaccharide-induced cytokine synthesis by human monocytes. Blood 1992:79:2364-2369.

(55) Fischer E, Van Zee KJ, Marano MA, Rock CS, Kenney JS, et al: Interleukin-1 receptor antagonist circulates in experimental inflammation and in human disease. Blood 1992:79:2196-2200

(56) Rogy MA, Coyle SM, Oldenburg HSA, Rock CS, et al: Persistently elevated soluble TNF receptor and interleukin-1 receptor antagonist levels in critically ill patients. J Am Coll Surg 1994;178:132-138.

(57) Fisher CJ jr, Agosti JM, Opal SM, et al: Treatment of septic shock with the TNF receptor: Fc fusion protein. $N$ Engl J Med 1996:334:1697-1701.

(58) Fisher CJ jr. Opal SM. Dhainaut JF. Stephens S. Zimmerman JL, et al: Influence of an anti-tumor necrosis factor monocional antibody on cytokine levels in patients
with sepsis. The CBOOO6 Sepsis Syndrome Study Group. Crit Care Med with sepsis. The

(59) Fisher CJ jr, Slotman GJ, Opal SM. Pribble JP, Bone RC, et al: Initial evaluation of human recombinant interleukin-1 receptor antagonist in the treatment of sepsis syndrome. A randomized open-label, placebo-controlled multicenter trial. Crit Care Med 1994:22:12-21.

(60) Echtenacher B. Falk W, Mannel DN, Krammer PH: Requirement of endogenous tumor necrosis factor/cachectin for recovery from experimental peritonitis. J Immunol 1990:145:3762-3766.

(61) Czuprynski CJ, Haak Frendscho M, Maroushek N, Brown JF: Effects of recombinunt human interleukin- 6 alone and in combination with recombinant interleukin- 1 alpha and tumor necrosis factor alpha on antibacterial resistance in mice. Antimicrob Agents Chemother 1992;36:68-70.

(62) Roll JT. Young KM, Kurtz RS, Czuprynski CJ: Human $r$ TNF alpha augments anti-bacterial resistance in mice: potentiation of its effects by recombinant human rIL-1 alpha. Immunology 1990:69:316-322.

(63) van der Meer JW, Vogels M, Curfs JH, Eling WM: Interleukin-1 as a possible agen for treatment of infection. Eur J Clin Microbiol Infect Dis 1993;12 (Suppl 1): S73-\$77. (64) van der Meer JW, Helle M, Aarden L: Comparison of the effects of recombinan interleukin 6 and recombinant interleukin 1 on non-specific resistance to infection. Eur J Immunol 1989;19:413-416

(65) Perez C, Albert I, DeFay K, Zachariades N, Gooding L, Kriegler MA: Non-secretable cell surface mutant of tumor necrosis factor (TNF) kills by cell-to-cell contact. Cell 1990;63:251-258

(66) Mathison JC. Wolfson E, Ulevitch RJ. Participation of tumor necrosis factor in the mediation of gram negative bacterial lipopolysaccharideinduced injury in tabbits. J Clin Invest 1988:81:1925-1937.

(67) Ginsberg HS, Moldawer LL, Sehgal PB, Redington M, Kilian PL, Chanock RM, Prince GA: A mouse model for investigating the molecular pathogenesis of adenovinus pneumon!a. Proc Natl Acad Sci USA ! 991;88:165!-1655.

(68) Marano MA, Moldawer LL, Fong Y, Wei H, Minei J, Yurt R, Cerami A, Lowry SF: Cachectin/TNF production in experimental burns and pseudomonas infection. Arch Surg 1988:123:1383-1388.

(69) Keogh C, Fong Y, Marano MA, Seniuk S, He W, Barber A, Minei JP, Felsen D. Lowry SF, Moldawer LL: Identification of a novel tumor necrosis factor alpha/ cachectin from the livers of burned and infected rats. Arch Surg 1990:125:79-84

(70) Ulich TR, Guo K, del Castillo J: Endotoxin-induced cytokine gene expression in vivo. Expression of tumor necrosis factor $m R N A$ in visceral organs under physiologic conditions and during endotoxemia. Am J Pathol 1989;134:11-14.

(71) Hyers TM, Tricomi SM, Dettenmeier PA, Fowler AA: Tumor necrosis factor levels in serum and bronchoalveolar lavage fluid of patients with the adult respiratory distress syndrome. Am Rev Respir Dis 1991:144:268-271

(72) Suter PM, Suter S, Girardin E, Roux Lombard P, Grau GE, Dayer JM: High bronchoalveolar levels of tumor necrosis factor and its inhibitors, interleukin-1, interferon, and efastase, in patients with adult respiratory distress syndrome after trauma, shock, or sepsis. Am Rev Respir Dis 1992;145:1016-1022.
(73) Ashkenazi A, Marsters SA. Capon DJ, Chamow SM, Figari IS, et al: Protection against endotoxic shock by a tumor necrosis factor receptor immunoadhesin. Proc Natl Acad Sci USA 1991:88:10535-10539.

(74) Beutler B, Cerami A: Cachectin and tumour necrosis factor as two sides of the same biological coin. Nature 1986;320:584-588

(75) Mancilla J, Garcia P, Dinarello CA: The interleukin-1 receptor antagonist can either reduce or enhance the lethality of Klebsiella pneumoniae sepsis in newborn rats. Infect Immun 1993:61:926-932

(76) Rothe J, Lesslauer W, Lötscher HR, lang Y. Koebel P, et al: Mice lacking the tumor necrosis factor receptor 1 are resistent to TNF-mediated toxicity but highly susceptible to infection by Listeria monocytogenes. Nature 1993;364:798-802. (77) Salmons B, Gunzburg WH: Targeting of retroviral vectors for gene therapy Hum Gene Ther 1993;4:129-14].

(78) Roe T, Reynolds TC, Yu G, Brown PO: Integration of murine leukemia virus DNA depends on mitosis. ENBO J 1993;12:2099-2108.

(79) Ellison V, Abrams H. Roe T, Lifson J, Brown P: Human immunodeficiency virus integration in a cell-free system. J Virol 1990;64:271 1-2715.

(80) Rogy MA, Auffenberg T, Espal NJ. Philip R, Remick D. Wollenberg GK Copeland EM, Moldawer LL: Human tumor necrosis factor receptor $(\mathrm{p} 55)$ and interleukin 10 gene transfer in the mouse reduces mortality to lethal endotoxemia and also attenuates local inflammatory responses. J Exp Med 1995;181:2289-2293.

(81) Hume DM. Benjamin T. Zukoski CF, Lee HM, Kaufmann HM. Egdahl RH: The homotransplantation of kidneys and of fetal liver and spleen after total body irradiation. Annals Surg 1960:152:354-373.

(82) Calne RY: Rejection of renal homografts: inhibition in dogs by 6 -mercaptopurine. Lancet 1960;:-417.

(83) Calne RY, Rolles K, Thiru S, McMaster P, et al: Cyclosporin A initially as the only immunosuppressant in 34 patients of cadaveric organs: 32 kidneys. 2 pancreas. and 2 livers. Lancet 1979:II:1033-1036.

(84) Starzl TE, Todo S, Fung J, Demetris AJ, Venkataramanan R, Jain A: FK 506 for human liver. kidney and pancreas transplantation. Lancet 1989:II:1000-1004.

(85) Alonso-Pulpon L, Serrano-Fiz S, Rubio JA. Cavero MA. Silva L, et al: Efficacy of low dose OKT3 as cytolytic induction therapy in heart transplantation. J Heart Lung Transpl 1995:14:136-1 4 ?

(86) Qin L, Chavin KD, Ding Y, Favaro JP, Woodward JE, et al: Multiple vectors effectively achieve gene transfer in a murine cardiac transplantation model. Transplantation 1995;59:809-816.

87) Qin L, Chavin KD, Ding Y. Woodward JE, Favaro JP, Lin J, Bromberg JS: Gene transfer for transplantation. prolongation of allograft survival with transforming growth factor- $\beta 1$. Ann Surg 1995:220:508-519.

(88) Larsen CP. Elwood ET. Alexander DZ, Ritchie SC, Hendrix R, et al: Long-term acceptance of skin and cardiac allografts after blocking CD 40 and $C D 28$ pathways. Nature 1996;381:434-438.

(89) Ding L, Linsley PS. Huang LY, Germain RN. Shevach EM: IL-10 inhibits macrophage costimulatory activity by selectively inhibiting the upregulation of 87 expression. J Immunol 1993:151:1224-1234.

From the Department of Experimental Surgery. Christian-Albrechts-University, Kiel, Germany

\section{Invited Commentary to: "Gene Therapy in Surgery"}

\section{J. Seifert}

The therapy of surgical patients does not end with a successful operation but has to be continued in intensive care wards, and by postoperative therapies to achieve a most complete cure of the disease. Thus it is important for all surgeons to keep informed about the latest therapeutic developments, and to apply new and promising techniques to the benefit of their surgical patients.

In a generally intelligible way, Rogy et al. (I) describe which surgical patients could be considered to receive human gene therapy in the near future, which methods may be applied, and which chances of success they have if cautiously weighed. Gene technology is a relatively new tool, thus we cannot decide presently if it would not benefit a series of other surgical diseases as well. The use of this technique might be considered for improving healing disorders of wound and bone, for inducing cartilage regeneration, and. it might bring us further ahead in the treatment of chronic pancreatitis, progressive cirhosis of he liver, emphysema, and many other diseases. As is the case with every new method, the limits of gene technology have to be first defined. Yet, the method is developing with breathtaking speed, and surgeons must take care that they will not again be faced with a new speciality splitting off and alienating surgery from a part of its tasks. Thus we are obliged to watch the potentials of gene technology very closely as they emerge, and to incorporate them in the field of surgery in a sensible way.

Corresponding address: J. Seifert, M.D., Department of Experimental Surgery, Christian-Albrechis-University, Arnold Heller Strabe 7, D-24105 Kiel, Germany. 